Brit. F. industr. Med., 1967, 24, 143.

\title{
Aspects of Pulmonary Mechanics in Arc Welders' Siderosis
}

\author{
DAN C. STÁNESCU ${ }^{1}$, LAURENTIU PILAT, NICULAE GAVRILESCU, \\ DAN B. TECULESCU, AND IULIA CRISTESCU
}

From the Department of Physiology and Occupational Disease, Institute of Hygiene; the Cardiopulmonary Laboratory, Clinic of Occupational Diseases, Colentina Hospital, and the Medical Department, Medical-Pharmaceutical Institute, Bucharest, Rumania

Sixteen working welders with more than seven years' exposure and a chest radiograph suggestive of siderosis and 13 healthy unexposed men were studied. Each subject had a comprehensive medical and work history, physical examination, standard chest film, and pulmonary function investigation (lung volumes, ventilatory capacities, pulmonary compliance in static and dynamic conditions, specific compliance, and elastic work of breathing).

Seven of the welders had some exertional dyspnoea and three complained of cough. Although spirographic values were generally within the normal range, the arc welders had a statistically significant reduction in static and functional compliance. Seven had a functional compliance under the lower limit of the control group. Differences in elastic work of breathing and specific compliance were not significant.

The possible causes of pulmonary function impairment in welders are discussed.

Since 1936, when Doig and McLaughlin reported their first cases, several studies have been devoted to the clinical, epidemiological, roentgenological, and functional aspects of welders' siderosis.

Most authors are agreed in considering this condition as harmless, with no impairment of the general health or respiratory function (Collen, 1947; Doig and Duguid, 1951; Doig and Challen, 1964; Enzer and Sander, 1938; Sander, 1944). However, some recent papers have questioned this view (Charr, 1955, 1956; Friede and Rachow, 196I; Kierst, Uselis, Graczyk, and Krynicki, I964; Sevčik, Chalupa, Klhufková, and Hrazdira, I960).

The purpose of the present work is to examine some aspects of pulmonary ventilation in welders at work and to assess the possible impairment of pulmonary elasticity.

\section{Material and Methods}

Fifty-two subjects were picked at random from the 70 welders of a metallurgical plant. Sixteen were then selected as having over seven years' exposure as arc welders and chest radiographs suggestive of siderosis. The International Labour Office. (1959) criteria for

${ }^{1}$ Address for reprint requests: Cardiopulmonary Laboratory, Clinic of Occupational Disease, Hospital Colentina, Bucharest I0, Rumania.

Received for publication May 2, 1966. evaluation of chest films were used. All subjects had a complete medical and work history, clinical examination, and standard chest postero-anterior film. Individuals with chronic cardiopulmonary disease or acute respiratory illness during the last six months period were excluded.

These 16 welders were compared with a control group of 13 normal individuals with no dust exposure. The ages and heights of subjects are presented in Table I. No significant differences in height, age, or smoking habits were found between the groups. The average duration of exposure was $17 \cdot 1$ years (range 7 to 30 years).

Lung function tests comprised determinations of lung volumes, forced expiratory volumes, helium-mixing time, and pulmonary mechanics. All determinations were carried out on fasting subjects in a sitting position. A 9-litre spirograph ${ }^{1}$ was used; residual volume was

TABLE I

Age AND Height of SubJects

\begin{tabular}{c|l|c|c}
\hline Group & & Age (years) & Height (cm.) \\
\hline & Mean & 36 & 176 \\
Normals & Range & $25-52$ & $168-186$ \\
(I3 cases) & S.D. & 8.4 & 5.9 \\
\hline & Mean & 39.6 & 166.5 \\
Welders & Range & $24-57$ & $156-175$ \\
(I6 cases) & S.D. & 9.9 & 5.2 \\
\hline P & & $>0.30$ & $>0.30$ \\
\hline
\end{tabular}




\section{I44 Dan C. Stănescu, Laurentiu Pilat, Niculae Gavrilescu, Dan B. Teculescu, and Iulia Cristescu}

measured by the closed-circuit helium dilution method. ${ }^{2}$ Helium-mixing time was recorded as an approximate index of the distribution of inspired gas. Normal values for V.C., R.V., R.V./T.L.C., and F.E.V.1.0 were derived from the tables of Jouasset (I960) which were similar to those of Kory, Callahan, Boren, and Syner (I96I) and Ferris, Anderson, and Zickmantel (I965).

Pressure volume (P.V.) loops were obtained on a mechanical co-ordinate recorder. ${ }^{3}$ Oesophageal pressure was measured with a latex balloon, $15 \mathrm{~cm}$. long and $12 \mathrm{~mm}$. in diameter, sealed over the end of a polyethylene catheter, $80 \mathrm{~cm}$. long and $1.5 \mathrm{~mm}$. i.d. The balloon was introduced into the lower third of the oesophagus (38 to $40 \mathrm{~cm}$. from the lips) and, following the method of Hamm (1960), the outer end of the catheter was left open for a few minutes. The volume of gas inside the balloon depended on the pressure gradient between the ambient and oesophageal pressure and was about I ml. Trans-pulmonary pressure was measured by a differential manometer ${ }^{4}$. Linearity of manometer response was checked daily by a water manometer.

At least ro P.V. loops in spontaneous breathing were recorded; trans-pulmonary pressure was measured at points of zero flow and tidal volume corrected to B.T.P.S. The $\Delta V / \triangle P$ ratio in spontaneous breathing represented functional compliance $\left(\mathrm{C}_{\mathrm{F}}\right)$. Compliance $\left(C_{S}\right.$ lin) was then determined in quasi-static conditions (very slow breathing with Io to 12 seconds for inspiration) by the method of Ehrner (I960); the $\triangle V / \triangle P$ ratio

'Pulmotest, Godart

'Pulmo Analysor, Godart

${ }^{3}$ Compliance test, Godart

'Pressure amplifier, Godart was measured on the linear portion of the inspiratory segment of a minimum of three loops and compliance values were expressed in $1 . / \mathrm{cm} . \mathrm{H}_{2} \mathrm{O}$.

The maximum negative inspiratory pressure $\left(P_{\mathrm{el}}\right.$ max) was measured at maximum inspiratory point. Compliance was also expressed as 'specific compliance', $\mathrm{C}_{\text {spec }}$ (Lim, Luft, and Grodins, I958), or $\mathrm{C}_{\mathrm{F}}$ per litre F.R.C. Elastic work in $\mathrm{gcm}$. per $\mathrm{ml}$. of gas ventilated was calculated in spontaneous breathing.

The data in Table IV represent the means of 10 values for $C_{F}, C_{\text {spec}}$, and $W_{e l}$ and of three values for $\mathrm{C}_{\mathrm{S}}$ lin, as well as standard deviation (S.D.), range (R), and statistical significance. Differences between arc welders and normals were ascertained by Student's ' $t$ ' test, including Yates' correction. Differences with $\mathbf{P}<0.001$ were considered highly significant, $P$ between 0.001 and 0.01 significant, and $P$ between 0.01 and 0.05 questionable.

\section{Results}

Table II shows the smoking habits, symptoms, and $X$-ray picture for each welder. There were only seven smokers among the welders, none of whom smoked more than 20 cigarettes daily.

Clinical abnormalities were scanty: slight dyspnoea ( 7 cases) and cough with increased expectoration ( 3 cases). The $X$-ray appearance in each subject according to the I.L.O. (I959) classification is also shown in Table II.

Table III presents spirographical data. Lung volumes were within normal limits, except for a slight decrease of V.C. in case 12 where it was $70 \%$

TABLE II

Exposure, Symptoms, Smoking Habits, and X-RAy Appearance in Welders

\begin{tabular}{|c|c|c|c|c|c|c|}
\hline No. & Subject & $\begin{array}{c}\text { Age } \\
\text { (yrs.) }\end{array}$ & $\begin{array}{c}\text { Duration of Service } \\
(\text { years })\end{array}$ & Symptoms & $\begin{array}{c}\text { Smoking Habits } \\
\text { (no. of cigarettes } \\
\text { daily/years) }\end{array}$ & $X$-ray category ${ }^{1}$ \\
\hline $\mathbf{I}$ & S.A. & 57 & 20 & - & 0 & p3 \\
\hline 2 & P.C. & 38 & 9 & Cough + sputum & 0 & pr \\
\hline 3 & D.I. & 43 & 30 & $\underset{\text { dyspnoea }}{\text { Cough }+ \text { sputum }}+$ & $20 / 30$ & p2 \\
\hline 4 & B.I. & 37 & 22 & Dyspnoea & ○ & p2 m2 \\
\hline 5 & R.N. & 33 & I8 & Dyspnoea & 0 & p2 \\
\hline 6 & O.G. & 39 & I7 & Dyspnoea & $10 / 14$ & p2 \\
\hline 7 & V.G. & 24 & 8 & Dyspnoea & 0 & p2 m2 \\
\hline 8 & 'M.R. & 30 & 14 & - & $20 / 12$ & p2 \\
\hline 9 & H.A. & 51 & 17 & Dyspnoea & $20 / 30$ & pr \\
\hline 10 & D.I. & $3 I$ & 14 & 一 & 0 & p2 m2 \\
\hline II & o.s. & 49 & 22 & - & $15 / 25$ & pI \\
\hline 12 & R.A. & 27 & 7 & 一 & $20 / 3$ & pr \\
\hline 13 & S.M. & 42 & 26 & - & 0 & pr \\
\hline I4 & P.S. & 38 & 13 & - & 0 & pr \\
\hline 15 & C.A. & 53 & 24 & Cough & 0 & p3 m3 \\
\hline 16 & G.D. & 52 & 27 & Dyspnoea & 0 & pi \\
\hline
\end{tabular}

${ }^{1}$ International Labour Office, 1959 
TABLE III

LUNG Volumes and Ventilation

\begin{tabular}{|c|c|c|c|c|c|c|c|c|c|c|c|}
\hline \multirow[b]{2}{*}{ Group } & & \multicolumn{2}{|c|}{ Vital Capacity } & \multicolumn{2}{|c|}{ Total Lung Capacity } & \multicolumn{2}{|c|}{ Residual Volume } & \multirow{2}{*}{$\underset{(\%)}{R . V . / T . L . C .}$} & \multicolumn{2}{|c|}{ F.E.V.1.0 } & \multirow{2}{*}{$\begin{array}{c}\text { Helium } \\
\text { Mixing } \\
\text { Time } \\
\text { (min.) }\end{array}$} \\
\hline & & ml.B.T.P.S. & $\begin{array}{c}\% \text { of } \\
\text { Predicted }\end{array}$ & ml. B.T.P.S. & $\begin{array}{c}\% \text { of } \\
\text { Predicted }\end{array}$ & ml.B.T.P.S. & $\begin{array}{c}\% \text { of } \\
\text { Predicted }\end{array}$ & & ml. B.T.P.S. & $\begin{array}{l}\% \text { of } \\
\text { V.C. }\end{array}$ & \\
\hline Normals & $\begin{array}{l}\text { Mean } \\
\text { Range }\end{array}$ & $\begin{array}{c}5,259 \\
4,750-6,000\end{array}$ & $\begin{array}{c}93 \cdot 7 \\
84-110\end{array}$ & $\begin{array}{c}6,719 \\
5,440-7,670\end{array}$ & $\begin{array}{c}93 \cdot 6 \\
8 I-I 05\end{array}$ & $\begin{array}{c}1,460 \\
600-2,440\end{array}$ & $\begin{array}{c}8 I \cdot 5 \\
38-I 43\end{array}$ & $\underset{I I-32}{20}$ & $\begin{array}{c}4,048 \\
3,340-4,750\end{array}$ & $\begin{array}{c}77 \cdot 1 \\
71-84 \cdot 5\end{array}$ & $\begin{array}{l}3 \cdot 8 \\
3-5\end{array}$ \\
\hline Welders & $\begin{array}{l}\text { Mean } \\
\text { Range }\end{array}$ & $\begin{array}{c}4,198 \\
3,170-5,150\end{array}$ & $\begin{array}{c}90 \cdot 2 \\
70-100\end{array}$ & $\begin{array}{c}5,658 \\
3,970-6,880\end{array}$ & $\begin{array}{c}91 \cdot 6 \\
80 \cdot 5-103\end{array}$ & $\begin{array}{c}1,460 \\
800-1,980\end{array}$ & $\begin{array}{c}99 \cdot 4 \\
58 \cdot 5-117\end{array}$ & $\begin{array}{l}25 \cdot 4 \\
16-37\end{array}$ & $\begin{array}{c}3,208 \\
2,440-3,830\end{array}$ & $\begin{array}{c}79 \cdot 5 \\
63-88\end{array}$ & $\begin{array}{c}4 \\
2 \cdot 5-5\end{array}$ \\
\hline
\end{tabular}

TABLE IV

Pulmonary Mechanics

\begin{tabular}{|c|c|c|c|c|c|c|}
\hline Group & & $\begin{array}{l}\text { Linear Static } \\
\text { Compliance } \\
\left(\text { l. } / \mathrm{cm} . \mathrm{H}_{2} \mathrm{O}\right)\end{array}$ & $\begin{array}{c}\text { Functional } \\
\text { Compliance } \\
\left(\text { l./cm. } \mathrm{H}_{2} \mathrm{O}\right)\end{array}$ & $\begin{array}{c}\text { Elastic Work } \\
(\mathrm{gcm} . / \mathrm{ml} .)\end{array}$ & $\begin{array}{c}\text { Specific Compliance } \\
\left.\text { (l./cm. } \mathrm{H}_{2} \mathrm{O} / \mathrm{l} . \text { F.R.C. }\right)\end{array}$ & $\begin{array}{c}\text { Maximum } \\
\text { Inspiratory } \\
\text { Pressure } \\
\left(\mathrm{cm} . \mathrm{H}_{2} \mathrm{O}\right)\end{array}$ \\
\hline Normals & $\begin{array}{l}\text { Mean } \\
\text { Range } \\
\text { S.D. }\end{array}$ & $\begin{array}{c}0.204 \\
0.158-0.281 \\
0.044\end{array}$ & $\begin{array}{c}0.157 \\
0.1 \text { I I }-0.206 \\
0.024\end{array}$ & $\begin{array}{c}2 \cdot 47 \\
I \cdot 62-4 \cdot 15 \\
0 \cdot 70\end{array}$ & $\begin{array}{c}0.045 \\
0.034-0.053 \\
0.0065\end{array}$ & $\begin{array}{c}24 \cdot 2 \\
12 \cdot 5-38 \cdot 0 \\
5 \cdot 9\end{array}$ \\
\hline Welders & $\begin{array}{l}\text { Mean } \\
\text { Range } \\
\text { S.D. }\end{array}$ & $\begin{array}{c}0.157 \\
0.106-0.234 \\
0.035\end{array}$ & $\begin{array}{c}0.120 \\
0.070-0.187 \\
0.0347\end{array}$ & $\begin{array}{c}2 \cdot 72 \\
I \cdot 50-3 \cdot 90 \\
0 \cdot 75\end{array}$ & $\begin{array}{c}0.040 \\
0.027-0.059 \\
0.0102\end{array}$ & $\begin{array}{c}23 \cdot 4 \\
\text { II. } 5-37 \cdot 0 \\
6 \cdot 2\end{array}$ \\
\hline $\mathbf{P}$ & & $0.01-0.001$ & $0.01-0.001$ & $>0.80$ & $0.10-0.20$ & $>0.60$ \\
\hline
\end{tabular}

of the predicted value; F.E.V.1.0/V.C. $\%$ of predicted was slightly lower in case I $(63 \%)$ and normal in the others. The helium-mixing time did not exceed the upper limit of normal values. Parameters of pulmonary mechanics are listed in Table IV.

The mean values of the normal subjects fall in the ranges of those obtained by other laboratories using similar methods. Welders had lower mean values for $C_{S}$ lin, $C_{F}, C_{\text {spece }}$, and a slightly lower value of $P_{e l}$ max; $W_{e l}$ was slightly increased.

The drop of $C_{S}$ lin and $C_{F}$ was statistically significant ( $P$ between $0.0 \mathrm{I}$ and $0.00 \mathrm{I}$ ); all other differences were not significant. Seven welders had compliance values $\left(\mathrm{C}_{F}\right)$ less than the lower limit of the normal group. The statistical significance of the fall in compliance was confirmed by an analysis of covariance to eliminate the possible influence of the subject's height $(\mathrm{F}=5 \cdot 20, \mathrm{P}<0.05)$.

\section{Discussion}

Roentgenological changes due to deposition of iron oxide in the pulmonary interstices have been described in arc welders. On the basis of statistical and other studies carried out in Great Britain, the United States, and elsewhere, this occupation was considered as benign with no impairment of capacity for work. Cough and shortness of breath were reported in isolated cases. However, recent investigations have shown impairment of respiratory function and pulmonary symptoms in these workers.

Pathological reports are scarce (Charr, 1955; Harding, McLaughlin, and Doig, 1958) due to the benign course. Lung biopsies have yielded few and contradictory reports (Charr, I955; Clements, 1962; Morgan and Kerr, 1963); some authors have found chronic inflammatory changes and fibrous proliferation as well as iron deposits (Charr, 1955; Harding et al., 1958).

Pulmonary function studies in arc welders have been limited to a few aspects, chiefly to spirographic tests (Charr, 1955; Hunnicutt, Cracovaner, and Myles, 1964; Kierst et al., 1964; Morgan and Kerr, 1963; Young, Shaw, and Bates, 1963). Most of them were done on small groups or represented case reports. The differences in spirographic values between I00 welders and 100 non-welders found by Hunnicutt and his colleagues (1964) were attributed to smoking. Recently Kierst and 


\section{I46 Dan C. Stănescu, Laurentiu Pilat, Niculae Gavrilescu, Dan B. Teculescu, and Iulia Cristescu}

his colleagues (1964) reported a decreased V.C. in approximately one-third of 173 arc welders examined, a rather large proportion and in conflict with earlier studies. In individual cases, undersaturation of arterial blood (Morgan and Kerr, I963) and an obstructive respiratory syndrome were noted (Charr, I955), but the relation between these findings and occupation is uncertain.

Compliance measurements have been made only by Morgan and Kerr (1963) in three cases: in one case the actual value was slightly lower than predicted.

Some of our subjects complained of cough with moderate expectoration and exertional dyspnoea. These symptoms did not seem to correlate with smoking: of three subjects with cough only one was a smoker; three smokers were among the seven subjects with breathlessness. The relationship between smoking habits and respiratory symptoms is complex and difficult to ascertain in individual cases.

The general appearance of the chest filmsreticulation with small nodules distributed throughout the lung-did not differ from that previously reported (Doig and McLaughlin 1936, I948; Britton and Walsh, 1940; Hunnicutt et al., 1964; Pilat, Lilis, and Craciun, 1963; Sander, 1944).

The absence of abnormality in our spirographic findings is in agreement with other investigations (Hunnicutt et al., 1964; Pilat et al., 1963).

The compliance values $\left(C_{S}\right.$ lin and $\left.C_{F}\right)$ were significantly lower in arc welders both by Student's ' $t$ ' test and by covariance analysis. Moreover, seven subjects had a functional compliance less than the lower limit for normals. Five of them complained of dyspnoea; only two out of seven were smokers. $C_{F}$ and $C_{S}$ lin were the measurements which differentiated arc welders from normals, despite comparable spirographic data.

The elastic work of breathing was increased in welders; the wide scatter of the results might be responsible for the lack of significance. In the seven subjects whose functional compliance was less than the lower limit for normals, the elastic work (3.32 $\mathrm{gcm} . / \mathrm{ml}$.) was $134 \%$ of the normal values.

$P_{\mathrm{el}}$ max, a subject-dependent parameter, failed to separate the groups. This parameter, which is considered valuable by some authors in the assessment of elastic recoil of the lung in emphysema or fibrosis (Macklem and Becklake 1963), probably does not reflect slight pulmonary involvement. In a previous study of silicosis (Teculescu, Stănescu, and Pilat, I965), a significant decrease in functional compliance (in the early stages) was not accompanied by a significant increase in $\mathrm{W}_{\mathrm{el}}$ and $\mathrm{P}_{\mathrm{el}} \max$.
The lack of a significant decrease in specific compliance might be explained by a slight increase in F.R.C. of welders. This parameter was proposed to correct compliance values for size of lung ( $\mathrm{Lim}$ et al., 1958), but as F.R.C. might change irrespective of compliance, the correction appears to be of doubtful validity (Pratt, 196I).

A low lung compliance is generally considered to be a sign of decreased pulmonary distensibility. However, present methods of investigation of pulmonary elastic properties afford, at best, a gross estimation of the overall stiffness of the lung (Radford, 1964).

Dependence of the compliance on lung size (Cook, Helliesen, and Agathon, 1958; Petit, Delhez, and Troquet, 1965), interference of surface tension in addition to pulmonary elasticity in generating the recoil pressure of the lung (Clements, 1962; Mead, 196I; Petit et al., 1965), errors associated with oesophageal pressure measurements (Fry, Stead, Ebert, Lubin, and Wells, 1952; Mead, 1961; Milic-Emili, Mead, and Turner, I964a; MilicEmili, Mead, Turner, and Glauser, 1964b; Petit et al., 1965), and, finally, an over-simple application of Hook's law (Gilbert, Eich, and Auchincloss, 1958) are among factors that call for caution when interpreting measurements of pulmonary elasticity. Therefore it would probably be more prudent to describe pulmonary damage in terms of compliance changes rather than to assume impairment of lung elasticity.

A decrease of pulmonary compliance in arc welders could be explained by iron deposits per se and/or possibly associated fibrosis. It should be stressed that our subjects were selected both by a long exposure and by a radiological appearance of siderosis.

A consideration of the occupational hazards of welding should not be restricted to iron aerosols, for ozone, nitrous oxides, as well as different substances present in welding fumes from rod coating (silica, asbestos, zinc, cadmium, chrome, manganese, etc.) are certainly involved and may contribute to pulmonary damage. Arc welding should be considered as an occupation with cumulative hazards.

Studies of respiratory function in welders should therefore include detailed information concerning the type and quantity of electrodes used, as well as ventilation conditions. Unfortunately, as in the present study, these data are rather difficult to acquire, especially for long periods retrospectively.

In studies like the present one, selection of subjects is a decisive step and a difficult one. Rejection of subjects with obvious cardiopulmonary 
disease not related to occupational hazards is easy, but subjects with a slightly obstructive syndrome and/or 'bronchitis' (whether or not associated with smoking), which might or might not be due to occupational factors, present a more difficult problem.

Our group was small; further larger studies should lead to a better understanding of respiratory involvement in arc welders.

Valuable information could be obtained by mechanical studies on siderotic cadaver lungs similar to those performed in other diseases (Hartung, 1959; Pratt, 196I).

A follow-up study in welders with low compliance would show if they develop a more severe functional impairment, perhaps with overt respiratory disease.

The technical assistance of Miss Manuela Moscovici is acknowledged.

\section{REFERENCES}

Britton, J. A., and Walsh, E. L. (1940). F. industr. Hyg., 22, 125.

Charr, R. (1955). Amer. Rev. Tuberc., 71, 877.

- (1956). Ann. intern. Med., 44, 806.

Clements, J. A. (1962). Scient. Amer., 207, Dec., p. 120.

Collen, M. F. (1947). F. industr. Hyg., 29, 113.

Cook, C. D., Helliesen, P. J., and Agathon, S. (1958). F. appl. Physiol., 13, 349.

Doig, A. T., and Challen, P. J. R. (1964). Ann. occup. Hyg., 7, 223.

- and Duguid, L. N. (195I). The Health of Welders. London, H.M.S.O.

-, and McLaughlin, A. I. G. (1936). Lancet, I, 77 I.

$\longrightarrow$, and - (1948). Ibid., I, 789.

Ehrner, L. (1960). Acta med. scand., 167, suppl. 353.

Enzer, N., and Sander, O. A. (1938). F. industr. Hyg., 20, 333.

Ferris, B. G., Anderson, D. O., and Zickmantel, R. (1965). Amer. Rev. resp. Dis., 91, 252.
Friede, E., and Rachow, D. O. (196I). Ann. intern. Med., $54,121$.

Fry, D. L., Stead, W. W., Ebert, R. V., Lubin, R. I., and Wells, H. S. (1952). F. Lab. clin. Med., 40, 664.

Gilbert, R., Eich, R. H., and Auchincloss, J. H., Jr. (1958). Amer. Rev. Tuberc., 77, 863.

Hamm, J. (1960). Klin. Wschr., 38, 1093.

Harding, H. E., McLaughlin, A. I. G., and Doig, A. T. (1958). Lancet, 2, 394.

Hartung, W. (1959). Beitr. path. Anat., 120, 178.

Hunnicutt, T. N. Jr., Cracovaner, D. J., and Myles, J. T. (1964). Arch. environm. Health, 8, 661.

International Labour Office, Reunion d'experts sur la classification internationale des radiographies des pneumoconioses (1959). Secur. Hyg. Trav., 9, 67.

Jouasset, D. (1960). Poumon, 16, II45.

Kierst, W., Uselis, J., Graczyk, M., and Krynicki, A. (1964). Bull. Inst. mar. Med. Gdansk, 15, 149.

Kory, R. C., Callahan, R., Boren, H. G., and Syner, J. C. (196I). Amer. F. Med., 30, 243.

Lim, T. P. K., Luft, U. C., and Grodins, F. S. (1958). F. appl. Physiol., 13, 317.

Macklem, P. T., and Becklake, M. R. (1963). Amer. Rev. resp. Dis., 87, 47.

Mead, J. (196I). Physiol. Rev., 41, 28I.

Milic-Emili, J., Mead, J., and Turner, J. M. (1964a). F. appl. Physiol., 19, 212.

$\longrightarrow,-,-1$ and Glauser, E. M. (1964b). Ibid., 19, 207.

Morgan, W. K. C., and Kerr, H. D. (1963). Ann..intern. Med., 58, 293.

Petit, J. M., Delhez, L., and Troquet, J. (1965). F. Physiol. (Paris), 57, 7.

Pilat, L., Lilis, R., and Cracium, O. (1963). Med. interna (Buc.), 15, 213.

Pratt, P. C. (1961). Amer. Rev. resp. Dis., 83, 419.

Radford, E. P., Jr. (1964). Handbook of Physiology. sect. 3, Respiration, Vol. I, p. 429. American Physiological Society, Washington.

Sander, O. A. (1944). F. industr. Hyg., 26, 79.

Sevčik, M., Chalupa, B., Klhufková, E., and Hrazdira, C. L. (1960). Zbl. Arbeitsmed., ro, 77.

Teculescu, D. B., Stănescu, D. C., and Pilat, L. (1965). Rev. Roum. Méd. Intern., 2, 487.

Young, W. A., Shaw, D. B., and Bates, D. V. (1963). Arch. environm. Hlth, 7, 337. 